Szreniawski, P. (2020). Wykluczenie społeczne z perspektywy teorii rywalizacji hierarchii. W: I. Lipowicz, M. Małecka-Łyszczek (red.). Ekonomia Społeczna. Wykluczenie społeczne (s. 13-21). Kraków: Uniwersytet Ekonomiczny w Krakowie. https://doi.org/10.15678/ES.2020.1.02

\title{
Wykluczenie społeczne z perspektywy teorii rywalizacji hierarchii
}

\section{Piotr Szreniawski}

\begin{abstract}
Streszczenie: Wykluczenie społeczne może być postrzegane jako przykład pozbawiania jednostki członkostwa w zrzeszeniu bądź jako znaczne ograniczanie praw danej hierarchii. W tym kontekście życie społeczne postrzegane w danym kraju jest nie tylko jako rywalizacja mniejszych hierarchii, ale także jako przykład działania hierarchii, obejmującej całą sferę publiczną. Celem artykułu jest wskazanie możliwości stosowania teorii rywalizacji hierarchii do analizy zagadnienia wykluczenia społecznego, ukazanego w różnych kontekstach. Wykluczenie społeczne można ukazywać także na przykładach zaczerpniętych z różnych dziedzin aktywności ludzkiej.
\end{abstract}

Słowa kluczowe: wykluczenie społeczne, rywalizacja, hierarchia, teoria, społeczeństwo Kody JEL: $\quad$ I30; Y80

\section{Wprowadzenie}

Metafora rywalizacji sportowej pozwala na dostrzeganie nie tylko zjawisk dotyczących zwycięstwa i przegranej, ale także szeregu innych zagadnień, łączących się z kwestiami z zakresu organizacji, sposobu sędziowania, udziału publiczności, znaczenia treningu, sponsorów czy zainteresowania mediów. Jednym z zagadnień dotyczących rywalizacji sportowej jest problematyka wykluczenia.

W starożytnych igrzyskach olimpijskich do udziału w zawodach dopuszczano mężczyzn, Greków - z nielicznymi wyjątkami. Organizacja meczów, turniejów czy igrzysk olimpijskich to zagadnienie dotyczące nie tylko rywalizacji o sponsorów czy uwagę publiczności, ale także całego szeregu kwestii związanych z szeroko i bardziej dosłownie rozumianą rywalizacją między zawodnikami i drużynami. W szerokim znaczeniu mówić możemy o zjawiskach dotyczących przyciągania jak najlepszych zawodników do udziału w danym turnieju, dostrzegać tu należy problemy prestiżu, kwestie finansowe czy inne zagadnienia, wpływające na udział danych zawodników w określonych wydarzeniach (choćby kwestie geograficzne i polityczne). W wąskim znaczeniu, rywalizacja między zawodnikami dotyczy uprawiania szeregu dyscyplin sportowych, w których wyłania się zwycięzcę. Wykluczenie w kontekście rywalizacji sportowej w znaczeniu wąskim może być elementem procesu wyłaniania zwycięzcy, ale w znaczeniu szerokim jest przede wszystkim elementem dyskryminacji czy też wskaźnikiem potocznie rozumianej ekskluzywności rozgrywek. 


\section{Sposób wykluczania}

Kwalifikacje i rywalizacja o awanse i o pozostanie w danej lidze, mogą być postrzegane jako sposób wykluczania. Jednostki i zespoły, którym nie udało się zakwalifikować do udziału w kolejnych etapach rywalizacji w pewien sposób mogą być postrzegane jako wykluczone. Zauważyć jednak należy, że wyłącznie brak udziału w kolejnych etapach może być mimo wszystko zjawiskiem znacząco odbiegającym od wykluczenia postrzeganego jako coś łączącego się z ograniczaniem praw danych jednostek lub grup. Jednakże dyskryminacja również wydaje się nie zawsze być immanentnym elementem wykluczenia, przede wszystkim w przypadku wykluczenia się z własnej woli.

Mamy zatem do czynienia ze spektrum, w ramach którego - kontynuując metaforę sportową - niektóre wykluczone jednostki nie są zainteresowane udziałem w rozgrywkach, inne zaś nie są do nich dopuszczane. Jednakże nawet w pierwszym przypadku nie mamy do czynienia z całkowitym wykluczeniem występowania dyskryminacji. Zinternalizowane dyskryminujące normy, niedopuszczające do rozgrywek określonych grup społecznych, niekiedy są postrzegane jako naturalne i przez to niedyskryminujące, ewentualnie wskazywane są inne powody, racjonalizujące wyłączenie danych grup z rozgrywek czy w ogóle z uprawiania sportu.

Innym zagadnieniem jest rozbicie systemu rozgrywek na określone kategorie, w ramach których grupy jednostek i grupy drużyn rywalizują pomiędzy sobą. W przypadku niektórych kryteriów, takich jak kryterium geograficzne, rozbicie cyklu rozgrywek na mniejsze elementy uznawane jest za uzasadnione czy nawet za konieczne. Wręcz samo zróżnicowanie form uprawiania sportu, zasad rozgrywania spotkań czy postrzegania kultury fizycznej w ogóle, mimo wielu podobieństw, różni się m.in. z powodu kształtowania się danych zjawisk w oddaleniu od innych kultur czy ośrodków. Niekiedy rozbicie rozgrywek na mniejsze kategorie służy mnożeniu zwycięzców, co może być różnie oceniane. Jednakże czasami wyłanianie lig czy kategorii dla wskazanych grup jest bardziej kontrowersyjne. Ligi organizowane dla osób charakteryzujących się określonymi cechami fizycznymi osób biorących udział w rozgrywkach niekiedy stanowi formę przeciwdziałania całkowitemu wykluczeniu takich osób z rozgrywek - np. w przypadku uprawiania danego sportu przez przedstawicieli mniejszości', jednak niekiedy wiąże się z dyskryminacją finansową czy z mniejszym zainteresowaniem takimi rozgrywkami.

Wykluczenie w kontekście sportu rozumiane może być dosłownie lub jako przenośnia. Podobnie w wielu innych dziedzinach możemy dostrzegać metaforyczny wymiar zjawisk związanych czy to z umiejscowieniem jednostki w hierarchii, czy to z wykluczeniem. Analiza zagadnienia wykluczenia społecznego w odniesieniu do zróżnicowanych sfer działalności człowieka w dużym wymiarze prowadzi do wniosków, że - mimo istnienia specyfiki wielu dziedzin istnieje wiele podobieństw czy też prawidłowości, określających sposoby, przyczyny i skutki wykluczania jednostek z udziału w życiu ogółu.

Mimo że pojęcie wykluczenia społecznego jest dosyć szeroko wykorzystywane, to nie zawsze pojęcie to używane jest w odniesieniu do jednolitych zagadnień, ponadto wskazać należy, że zastąpiło ono - czy to w oficjalnych dokumentach, czy w dyskursie naukowym - szereg różnorodnych pojęć, takich jak bieda czy marginalizacja. Oczywiście różne pojęcia nadal

\footnotetext{
Choć ocena konkretnych przypadków związanych z tym zjawiskiem może wyglądać różnie. Niekiedy takie wyodrębnienie może być etapem pośrednim, przygotowującym do włączenia przedstawicieli mniejszości do udziału w wydarzeniach sportowych głównego nurtu, ale czasem właśnie taka odrębność służy ochronie tożsamości grupy, czy też jest szansą na wyrównaną rywalizację.
} 
określają wiele zagadnień pokrewnych do zagadnienia wykluczenia społecznego, niejednokrotnie wskazując na wybrany kontekst, np. ekonomiczny czy też kulturowy (Peace, 2001, s. 17).

Poza zastępowaniem pojęć ze względu na ich mniej neutralne brzmienie, pojęcie wykluczenia społecznego wykorzystywane jest jako pojęcie bardziej ogólne wobec wielu pojęć, będących niekiedy również określeniami odnoszącymi się do symptomów wykluczenia społecznego. Przykładowo, pojęcia bezdomności czy slumsów na różne sposoby określają zagadnienia związane z wykluczenia społecznym, odnoszące się do pewnego wycinka znaczeniowego pojęcia wykluczenia społecznego, widzianego w kontekście problemów z miejscem do mieszkania (Rodgers, 1995, s. 43).

\section{Korzyści i koszty}

Dostrzeganie korzyści jednostki z przynależności do hierarchii, np. w zakresie dostępu do dóbr, powinno również obejmować skutki przynależności do tejże hierarchii dla grupy. Koordynacja działań wielu jednostek, nie tylko ze względu na przepływ informacji, ale także na podporządkowanie i możliwość nakazywania czy też skłaniania jednostki do określonych zachowań, może być postrzegana jako korzyść dla całości hierarchii (Dubois i Ordabayeva, 2015, s. 335).

Z drugiej strony zauważać należy koszty, jakie zarówno grupa, jak i jednostka, ponoszą ze względu na przyjęcie danej osoby do wybranego szeroko rozumianego zrzeszenia. Jeśli ekskluzywność grupy postrzegana jest jako elitarność a nie jako zjawisko aspołeczne czy choćby niemodne, to wykluczenie wydaje się zjawiskiem koniecznym dla podtrzymania atrakcyjności grupy elitarnej. Przyjmowanie jednostek uznawanych za niepożądane łączy się z ryzykiem utraty prestiżowego charakteru danego zrzeszenia.

Podobnie jak w chórze, gdzie śpiewy jednostek łączą się w sposób bardziej zgodny, kiedy te jednostki nastawione są na współtworzenie całości, a nie na zwracanie uwagi na siebie, tak w hierarchii chęć służenia dobru całości pomaga na sprawniejsze osiąganie celów (Bruckert i in., 2010, s. 118). Jednakże czy to dyrygent, czy zapis nutowy dyktują osobom śpiewającym, co mają one śpiewać - jeśli wykorzystamy ten przykład jako metaforyczny materiał do uogólnienia, to zauważymy, że o zachowaniach osób należących do hierarchii decydują zarówno jednostki stojące na szczycie tychże hierarchii, jak i systemy norm, którymi dana hierarchia się kieruje. Oczywiście kiedy mówimy o systemie norm, ucieleśnionym choćby w postaci zapisu nutowego, to pamiętamy, że nie tylko kompozytor, ale także jego epoka czy też szkoła, do której przynależy, wpływają na formę - i w pewnym stopniu także na treść - danego utworu. Jeśli tę przenośnię wykorzystamy do spojrzenia na zagadnienie źródeł prawa, a także do kwestii związanych z wykonywaniem i przestrzeganiem prawa, to dostrzeżemy nie tylko cały szereg powiązań pomiędzy czynnikami wpływającymi na konkretny przypadek, ale również znaczenie dobrej woli, rozumianej w sposób podobny do braku samolubności, dla zgodnego współistnienia jednostek w ramach społeczeństwa.

Jednakże samolubność nie jest jedynym kryterium, jakie może być tu brane pod uwagę. Dostrzegać tu należy także zjawiska takie jak przydatność, czy nawet przeciętność, dla akceptowania jednostki przez grupę, czy też dla pozycji jednostki w hierarchii. O ile nieprzeciętność tolerowana jest zwykle na wyższych pozycjach w hierarchii, o tyle przeciętność lepiej widziana jest bliżej podstaw hierarchii. Oczywiście nie należy takiego uogólnienia doprowadzać do absurdu, ani pomijać patologicznego wymiaru zjawisk z nim zgodnych - bogactwo i zróżnicowanie jednostek współtworzących podstawy hierarchii wydają się nawet być koniecznym elementem wysokiego rozwoju kultury. 
Wielkie znaczenie kultury, np. twórczości artystycznej, dla umiejscowienia jednostek w hierarchii, przejawia się na wiele różnych sposobów (Sorokin, 2010, s. 2). Udział w życiu kulturalnym w wielu społeczeństwach, z jednej strony charakteryzuje elity mające określone zasoby wolnego czasu, ale z drugiej strony postrzegany jest jako coś łączonego ze swoistym marginesem społecznym, tutaj rozumianym jako niepraktyczne czy nawet niezrozumiałe poświęcanie się sztuce. Zagadnienie to tylko pozornie jest paradoksalne i charakteryzuje wiele kultur i zjawisk zachodzących w różnych epokach. Oczywiście także i w omawianym kontekście pewna doza przeciętności czy też niewyróżniania się jest zwykle zjawiskiem przeważającym, dzięki czemu zajmowanie się sztuką może być tolerowane - czy to jako coś użytecznego ze względu na powstające dzieła, czy też ze względu na pełnienie przez ekspresję artystyczną roli wentyla bezpieczeństwa. Aby wyczuwać znaczenie wykorzystywanych pojęć, stwierdzić należy, że w omawianym kontekście wykluczenie społeczne wiąże się nie tylko z brakiem akceptacji dla skrajnych postaw artystycznych, ale także z brakiem dostępu do dzieł sztuki czy też z brakiem możliwości współtworzenia kultury.

Dosłownie rozumiane wykluczenie w zakresie kultury, czyli brak udziału w życiu kulturalnym społeczeństwa, wiąże się z uniemożliwieniem rozwijania talentów przez jednostki, ale także z brakiem promocji jednostek przynależących do grup wykluczonych. Dyskryminacja w tym kontekście nie musi oznaczać całkowitego braku dostępu do kultury, nie mamy zatem do czynienia z wykluczeniem. Jeśli jednak dostęp do kultury ma tylko nieliczna część społeczeństwa, możemy mówić nawet o wykluczeniu większości.

Wyczuwamy, że pojęcie wykluczenia większości bardziej odnosi się do warunków, gdzie elity celowo uniemożliwiają szerokim rzeszom społeczeństwa choćby niewielki rozwój, mimo istnienia obiektywnych możliwości zmiany stanu rzeczy - zjawisko takie zachodzi zwykle pod koniec epok, lecz koniecznym warunkiem zaistnienia zmiany epoki jest najczęściej nie tylko pojawienie się zmian technologicznych, ale także potrzeba zauważenia niesprawiedliwości istniejącego układu relacji społecznych, czy też przynajmniej dostrzeżenie potencjału jednostek i grup wykluczonych². Walka z analfabetyzmem i uwłaszczenie chłopów mogą być postrzegane jako przykłady zwalczania wykluczenia szerokich grup społecznych, jednakże zauważyć należy, że często pojęcie wykluczenia społecznego używane jest w odniesieniu do aktualnych relacji społecznych, najczęściej w kontekście braku dostępu do szans związanych z korzystaniem z udogodnień zapewnianych przez państwa dobrobytu.

\section{Dekonstrukcja pojęcia wykluczenia}

Dekonstrukcja pojęcia wykluczenia społecznego może odwoływać się do rozumienia pojęcia kluczenia jako częstego zmieniania kierunku drogi, stąd wykluczenie w kontekście społecznym to pójście inną drogą, niż ogół społeczeństwa. Samotność czy też samodzielne wykluczenie się z życia społecznego może zajść ze względu na przeżyte niepowodzenia (Gutowska, 2006, s. 218). Współczesne społeczeństwo indywidualistów w wielu wypadkach jest również społeczeństwem, gdzie depresja jest zjawiskiem szeroko spotykanym (Minois, 2018, s. 494). Ewolucyjne uwarunkowania dotyczące przetrwania jednostek współpracujących z grupą wpływają na łączenie się samotności z przykrymi odczuciami. Z drugiej strony samotność może być doceniana jako okazja do rozmyślań czy do skupionej pracy (Thoreau, 2010, s. 153).

Zaznaczyć należy, że pojęcie wykluczenia społecznego nie tyle obejmuje zagadnienia związane z brakiem praw, ile brak uczestniczenia w życiu gospodarczym czy społecznym - zatem raczej nie odnosi się do niewolnictwa. 
Dzikość, jak i przeciwstawione jej dążenie do życia zgodnego z wymogami społeczeństwa, istnieją w człowieku obok siebie. Dzikość, mimo jej tłumienia i ukrycia, niejednokrotnie wydaje się być czymś kuszącym i ciekawszym niż spokojne życie społeczne (Barański, 2000, s. 52). Zagadnienie zalet, a nawet tylko przyczyn istnienia zjawiska wykluczenia jest kontrowersyjne i powinno być analizowane z dużą ostrożnością. Błąd naturalistyczny, oparty na rozumowaniu, że skoro określony stan istnieje, to jest to uzasadnione czy nawet dobre, wykorzystywany jest także w omawianym kontekście (Jedynak, 1967, s. 290). W wielu przypadkach można dostrzegać znaczenie subiektywnej oceny uciążliwości lub wartości samotności, jednakże być może uzasadnione jest także zauważanie obiektywnych cech z nią związanych (Domeracki, 2018, s. 126). Podstawową jej wadą jest brak pomocy ze strony otoczenia.

Nie tylko brak pomocy, ale wręcz zwalczanie i niszczenie grup posiadających inne stanowisko niż hierarchia dominująca choćby w kwestiach kultury, zbliża kwestie związane z oddalaniem się od głównego nurtu z zagadnieniem wykluczenia. Wystawa sztuki zdegenerowanej w nazistowskich Niemczech była jednym z przykładów wykluczenia dużej części społeczności artystycznej. Klaustrofobiczne warunki prezentowania obrazów na wystawie, połączone z komentarzami mającymi ośmieszyć prezentowaną twórczość, skutecznie wpływały na negatywny odbiór tejże wystawy ze strony szerszej publiczności. Wykluczenie dzieł niezgodnych z panującą ideologią odbywało się także przy pomocy używanego języka, naśladującego mówienie o zarazkach (Hümme, 2005, s. 7). Język wykluczenia w wielu wypadkach przenika do głównego nurtu i w sposób nieuświadomiony używany jest przez osoby mające jak najlepszą wolę i wolne od zbrodniczych zamiarów (Brüning, 2017, s. 232). Dominujący związek wyznaniowy, mający ambicje objęcia swoim oddziaływaniem całości życia społecznego, często posługuje się metodą wykluczania, choćby uniemożliwiając prezentowanie dzieł niezgodnych z określoną ideologią religijną. Wykluczenie z przestrzeni publicznej - również w zakresie kształtowania tej przestrzeni - z pewnością jest formą wykluczenia (Abłażewicz-Górnicka, 2013, s. 232).

W perspektywie teorii rywalizacji hierarchii należy uwagę zwrócić na wykluczenie jednostki z hierarchii, do której ta jednostka należała, ale także na wykluczenie mniejszej hierarchii poprzez ograniczenie praw jej członków. Zauważać należy także m.in. kwestie dotyczące zmian na szczycie hierarchii i wpływu tych zmian na przyznawanie lub odbieranie praw danym jednostkom i ich grupom. Skrajnym przypadkiem wykluczenia jest zabicie danej jednostki, jednakże zbudowane jako analogia pojęcie śmierci cywilnej, czy też wygnanie także należą do form eliminujących jednostkę z życia społeczności. Poszczególne zrzeszenia mogą pozbawiać jednostkę możliwości brania udziału w ich działalności poprzez pozbawienie członkostwa lub poprzez ograniczenie praw.

Zwrócić należy uwagę na powiązania istniejące między hierarchiami dwóch rodzajów ${ }^{3}$ zrzeszenia tworzą swoje normy, a systemy norm odnoszą się do członków szeroko rozumianych zrzeszeń - choćby takich jak tradycyjnie rozumiane państwo. Możliwość posiadania praw tylko przez osoby zajmujące określone miejsce w hierarchii wskazuje nie tylko na znaczenie hierarchii w kontekście zjawiska wykluczenia, ale także rolę norm prawnych, zarówno w budowaniu i utrwalaniu hierarchii, w zakresie wykluczania jednostek, jak i w zakresie przeciwdziałania wykluczeniu.

Teoria rywalizacji hierarchii wyróżnia dwa sposoby zmiany na szczycie hierarchii - pierwszym jest rewolucja, czyli zmiany zachodzące wewnątrz hierarchii oraz inwazja, dotycząca 
zajęcia szczytu hierarchii przez inną hierarchię. Zjawiska inwazji przykładowo obejmują procesy związane z zajmowaniem kolonii albo z przyłączeniem organizacji słabszej do silniejszej. Pojęcie rewolucji odnosi się do procesów zachodzących w wielu organizacjach, co niekiedy może przypominać metaforyczny sposób używania tego pojęcia. W kontekście wykluczenia społecznego, zarówno inwazja, jak i rewolucja, często prowadzą do obniżania praw niektórych grup społecznych i przyznawania większych praw innym grupom. Przy znacznym ograniczaniu praw grup dawniej uprzywilejowanych mogą pojawiać się typowe symptomy wykluczenia społecznego rozumianego w szeroko przyjęty sposób - czyli bieda i brak udziału w życiu społecznym - jednakże dostrzegać należy także inne warianty dotyczące działań wobec przedstawicieli dawnych grup uprzywilejowanych - od ich zabijania do przekazywania im określonych przywilejów materialnych w zamian za ograniczenie praw politycznych.

\section{Wykluczenie zdolnych i sfera edukacji}

Z perspektywy teorii rywalizacji hierarchii szczególnie interesujące jest zjawisko wykluczania jednostek zdolnych. Wynikające z obawy o dokonanie rewolucji - rozumianej jako zmiana na szczycie hierarchii - zwalczanie konkurencji może przybierać różne formy, od rozpuszczania plotek, czy też pomijania przy rozdzielaniu nagród, aż do ludobójstwa. Zwykle uważa się, że nie tyle obojętność, co poniżenie jednostek i grup jest sposobem pozbawiania ich praw (Herrmann, 2011, s. 133).

Często takie "wykluczanie zdolnych" obejmuje jednak pomijanie tych osób w relacjach medialnych $^{4}$ (Zbyrad, 2013, s. 96), czy w opracowaniach naukowych. Zauważyć przy tym należy, że konkurowanie pomiędzy ambitnymi czy też zdolnymi jednostkami w danej dziedzinie, nie musi obejmować zjawiska zwalczania jednostek położonych niżej przez jednostki zajmujące najwyższe miejsca w tej samej hierarchii, ale jest w wielu wypadkach spotykane w konkurencji pomiędzy jednostkami zajmującymi nawet równorzędne pozycje w danej hierarchii.

Wykluczenie zdolnych wynika przede wszystkim z kompleksów jednostek zajmujących najwyższe stanowiska w danej hierarchii. Przeciwdziałanie takiemu wykluczeniu lub jego skutkom może polegać zarówno na dążeniu do wybierania na najwyższe stanowiska osób posiadających jak najlepsze cechy charakteru, na jak najlepszym przygotowaniu grup przeznaczonych do zajmowania wysokich stanowisk, ale także na budowaniu określonych wentyli bezpieczeństwa - takich jak podział władzy, czy nawet w formie instytucji błazna. Dodatkowo sposobem na uniknięcie podejmowania wobec zdolnych jednostek działań skrajnych jest zapewnienie należytej autonomii uniwersytetów czy innych hierarchii w pewien sposób odizolowanych od hierarchii władzy w kraju. Zauważyć należy, że omawiane wykluczenie zdolnych prowadzi do obniżania jakości kadr, poprzez wyeliminowanie jednostek kompetentnych z działań zbiorowości działającej w danej dziedzinie, bądź poprzez nieodpowiednie wykorzystanie wiedzy i umiejętności tych jednostek.

Należy zastanowić się, na ile zjawisko wykluczenia społecznego jest stopniowalne - to znaczy czy tylko wykluczenie związane z przejawami uznawanymi za typowe, takimi jak bezdomność czy bezrobocie - jest wykluczeniem społecznym (Nesterowicz, 2013, s. 29). Mimo że taki właśnie sposób wykorzystania pojęcia wykluczenia społecznego dominuje w literaturze, to moim zdaniem każde wykluczenie ze zrzeszenia jest jakąś formą wykluczenia społecznego.

Dodać należy, że pojęcie wykluczenia medialnego obejmuje cały szereg zjawisk, odnoszących się nie tyle do bycia pomijanym przez media, co brak dostępu do informacji przekazywanych przez media i brak informacji o danej grupie w środkach masowego przekazu. 
Mimo dalszej przynależności do aktywnej czy nawet uprzywilejowanej części społeczeństwa, brak możliwości udziału w aktywnościach danej hierarchii pozbawia jednostkę wielu relacji społecznych (Pedwell, 2016, s. 14). Szerokie znaczenie wykluczenia społecznego z jednej strony tworzy ryzyko utrudnień w komunikacji w badaniach nad zjawiskami przeciwdziałaniu biedzie, bezdomności czy innych problemów dotyczących grup najbardziej pomijanych i pokrzywdzonych, a z drugiej strony wskazuje na podobieństwo zjawisk zachodzących przy wykluczaniu jednostek z różnych hierarchii ${ }^{5}$.

Wykluczenie całej hierarchii odnosi się do przypadków dyskryminacji grup posiadających określone struktury organizacyjne i własne normy, dotyczy zatem dyskryminacji np. ze względu na przynależność do danej grupy etnicznej czy wyznaniowej. Ludobójstwa obejmujące sympatyków określonych ideologii politycznych często nie opierają się na badaniach poglądów przedstawicieli tych grup, tylko na dostrzeganiu ich przynależności do określonej hierarchii (Becker-Pestka i in., 2017, s. 48). Ponadto proces wykluczania całej hierarchii może opierać się na próbach przekonywania całości społeczeństwa o szkodliwości tejże hierarchii, np. poprzez krytyczne jej przedstawianie w ramach procesu edukacji, jak też np. w promowanych opracowaniach historycznych.

Zauważyć przy okazji należy, że zjawisko wykluczenia społecznego dotyczy także pamięci, czy też procesu pisania historii. Wobec pomijanych w kronikach rywali politycznych króla zwykle więcej jest niechęci, niż nawet wobec osób opisanych w sposób krytyczny. Upodabnianie przeciwnika politycznego do tysięcy osób na tyle nieistotnych, aby pisać o nich w kronikach, jest nie tylko formą upokorzenia, ale także wykluczenia. Ponadto eliminacja pamięci o konkurentach lub o ich osiągnięciach służy unikaniu rozważań o potencjalnych innych rozwiązaniach w zakresie ustroju.

Niezwykle ważnym obszarem wykluczenia jest sfera edukacji. Obowiązek szkolny wiąże szerokie rzesze społeczeństwa z procesem edukacji szkolnej, sytuując jednostki pozbawione edukacji szkolnej na marginesie życia społecznego. Z perspektywy teorii rywalizacji hierarchii edukacja często służy nie tylko nauczaniu jednostki jak wypełniać swoją rolę w ramach hierarchii, ale także wspinaniu się jednostki w ramach hierarchii. Powiązanie pozycji społecznej z edukacją ma charakter wielowymiarowy. Edukacja może być traktowana jako sposób przeciwdziałania niesprawiedliwościom społecznym i wyrównywania szans, ale także może być przejawem umacniania i potwierdzania uprzywilejowania lub jego braku. Poczucie zbędności, wynikające choćby z niedostosowania edukacji jednostki do zapotrzebowania na pracę, z braku celów czy z obojętności otoczenia na losy danej osoby, najczęściej nie staje się podstawą buntu, ale raczej przynosi rezultat w postaci wyłączenia się jednostki z życia społecznego (Bauman, 2004, s. 11).

\section{Literatura}

Abłażewicz-Górnicka, U. (2013). Marginalizacja i wykluczenie społeczne w przestrzeni miejskiej. Pogranicze. Studia Społeczne, 22, 231-242.

Barański, J. (2000). Samotność i nostalgia - Szkice z filozofii kultury. Wrocław: Wydawnictwo Akademii Ekonomicznej im. Oskara Langego we Wrocławiu.

Bauman, Z. (2004). Wasted Lives: Modernity and its Outcasts. Cambridge: Polity Press.

Zauważać należy wykluczenie „w bok”, poza hierarchię i wykluczenie „w dół” - na sam spód hierarchii - to drugie obejmuje zagadnienia związane z wykluczeniem społecznym rozumianym w sposób aktualnie używany w dokumentach Unii Europejskiej i w pracach socjologów. 
Becker-Pestka, D., Kubiński, G., Łojko, M. (2017). Różne obszary wykluczenia społecznego w Polsce - wybrane zagadnienia. Wrocław: Wydawnictwo Exante.

Bruckert, L., Bestelmeyer, P., Latinus, M., Rouger, J., Charest, I., Rousselet, G.A., Kawahara, H., Belin, P. (2010). Vocal Attractiveness Increases by Averaging. Current Biology, 20(2), 116-120. https://doi.org/10.1016/j. cub.2009.11.034

Brüning, C.I. (2017). Insights into the German Interviews of the Kestenberg Archive: Children of Perpetrators and How They Dealt with Their Parents' Actions. W: S.K. Cohen, E. Fogelman, D. Ofer (red). Children in the Holocaust and its Aftermath: Historical and Psychological Studies of the Kestenberg Archive (s. 224-246). New York-Oxford: Berghahn.

Domeracki, P. (2018). Horyzonty i perspektywy monoseologii. Toruń: Wydawnictwo Naukowe Uniwersytetu Mikołaja Kopernika.

Dubois, D., Ordabayeva, N. (2015). Social Hierarchy, Social Status and Status Consumption. W: M.I. Norton, D.D. Rucker, C. Lamberton (red.). The Cambridge Handbook of Consumer Psychology (s. 332-367). Cambridge: Cambridge University Press.

Gutowska, A. (2006). Hikikomori - samotność w XXI wieku. W: P. Domerack, W. Tyburski (red.). Zrozumieć samotność - Studium interdyscyplinarne (s. 217-228). Toruń: Wydawnictwo Uniwersytetu Mikołaja Kopernika.

Herrmann, S.K. (2011). Social Exclusion - Practices of Misrecognition. W: P. Kaufmann, H. Kuch, C. Neuhäuser, E. Webster (red.). Humiliation, Degradation, Dehumanization - Human Dignity Violated (s.133-150). DordrechtHeidelberg-Londyn-Nowy Jork: Springer.

Hümme, H. (2005). Künstlerischer Opportunismus in der Malerei und Plastik des Dritten Reiches. Brunszwik (maszynopis).

Jedynak, S. (1967). Błąd naturalistyczny, Etyka, 2, 289-297.

Minois, G. (2018). Historia samotności i samotników. Warszawa: Wydawnictwo Aletheia.

Nesterowicz, R. (2013). Wykluczenie społeczne w dobie kryzysu. W: M. Pokrzywa, S. Wilk, Wykluczenie społeczne. Diagnoza, wymiary i kierunki działań, (s. 25-43). Rzeszów: Wydawnictwo Uniwersytetu Rzeszowskiego.

Peace, R. (2001). Social Exclusion: A Concept in Need of Definition?. Social Policy Journal of New Zealand, 16, $17-36$.

Pedwell, C. (2016). Transforming habit: revolution, routine and social change. Cultural Studies, 31(1), 93-120. DOI: 10.1080/09502386.2016.1206134.

Rodgers, G. (1995). What is special about a "social exclusion” approach? W: G. Rodgers, C. Gore, J.B. Figueiredo (red.). Social exclusion: rhetoric, reality, responses (s.43-56). Genewa: International Institute for Genewa.

Sorokin, P. (2010). Social and Cultural Dynamics - A Study of Change in Major Systems of Art, Truth, Ethics, Law, and Social Relationships. New Brunswick-London: Transaction Publishers.

Thoreau, H.D. (2010). Walden, czyli życie w lesie. Poznań: Dom Wydawniczy Rebis.

Zbyrad, T. (2013). Wykluczenie społeczne a wykluczenie medialne. Annales Universitatis Paedagogicae Cracoviensis, Studia Sociologica, 1, 96-107.

\section{Social exclusion from the perspective of hierarchy competition theory}

Summary: Social exclusion can be viewed as an example of depriving an individual of membership in an association or as a significant restriction of rights within a given hierarchy. In this context, social life in a given country can be analysed as not only competition between smaller hierarchies, but also as a hierarchy covering the entire public sphere. The purpose of the article is to indicate the possibility of using the hierarchy competition theory to analyse the issue of social exclusion, shown in different contexts. Social exclusion can also be illustrated by examples taken from various fields of human activity.

Keywords: social exclusion, rivalry, hierarchy, theory, society

JEL codes: 130, Y80

\section{Informacje o autorze}

\section{Piotr Szreniawski}

ORCID: 0000-0002-3448-0298

Katedra Prawa Administracyjnego i Nauki o Administracji

Wydział Prawa i Administracji 


\section{Prawa autorskie i licencja / Copyright and License}

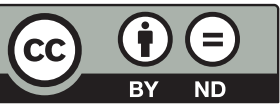

BY ND
Publikacja na licencji Creative Commons Uznanie autorstwa Użycie niekomercyjne - Bez utworów zależnych 4.0 Międzynarodowe (CC BY-ND 4.0) http://creativecommons.org/licenses/by-nc-nd/4.0/deed/pl

This work is published under the terms of the Creative Commons Attribution - NoDerivetives International (CC BY-ND 4.0) License http://creativecommons.org/licenses/by-nc-nd/4.0

Wydane przez Uniwersytet Ekonomiczny w Krakowie. Małopolska Szkoła Administracji Publicznej

Published by Cracow University of Economics - Krakow, Poland. Małopolska School of Public Administration of the Cracow University of Economics 